\title{
Switching toxin production on and off: intermittent microcystin synthesis in a Microcystis bloom
}

Susie A. Wood, ${ }^{1 *}$ Andreas Rueckert, ${ }^{2}$

David P. Hamilton, ${ }^{2}$ S. Craig Cary ${ }^{2,3}$ and

Daniel R. Dietrich ${ }^{4}$

${ }^{1}$ Cawthron Institute, Nelson, New Zealand.

${ }^{2}$ Department of Biological Sciences, University of Waikato, Hamilton, New Zealand.

${ }^{3}$ College of Marine and Earth Studies, University of

Delaware, Newark, DE, USA.

${ }^{4}$ Faculty of Biology, University of Konstanz, Konstanz, Germany.

\section{Summary}

Toxic cyanobacterial blooms are increasing in prevalence. Microcystins are the most commonly produced cyanotoxin. Despite extensive research the variables regulating microcystin production remain unclear. Using a RT-QPCR assay that allowed the precise measurement of mcyE transcriptional gene expression and an ELISA that enabled small changes in total microcystin concentrations to be monitored, we demonstrate for the first time that microcystin production is not always constitutive and that significant up- and downregulation in microcystin synthesis can occur on time scales of 2-6 h. Samples were collected over 3 days from a small eutrophic lake during a dense microcystin-producing Microcystis bloom. McyE gene transcripts were detected in only four out of 14 samples. Vicissitudes in both microcystin quotas and extracellular microcystin levels corresponded with changes in mcyE expression. During the period of exalted microcystin synthesis Microcystis sp. cell concentrations increased from 70000 cells ml mb $^{-1}$ to 4000000 cells $\mathrm{ml}^{-1}$. These data provide compelling evidence that changes in Microcystis cell concentrations influence microcystin production.

\section{Introduction}

Anthropogenic eutrophication, catchment modification and climate change have been linked to a global intensification of cyanobacterial blooms (Paerl and Huisman, 2008; Conley et al., 2009). The cyanobacteria responsible

correspondence. E-mail susie.wood@cawthron.org.nz; $\quad{ }^{*}$ Ter (+64) 3548 2319; Fax (+64) 35469464. for these blooms commonly produce toxic compounds and contact with, or consumption of contaminated water poses a serious health risk to humans, livestock, pets and wildlife (Codd et al., 2005). Toxic blooms have resulted in immeasurable costs to tourism, agriculture, farming and human health worldwide.

Of the known cyanotoxins the hepatotoxic microcystins are the most notorious. Microcystins, of which more than 80 different congeners have been identified (Zurawell et al., 2005), are found ubiquitously worldwide. They are well known for their role in the human fatalities in 1996 when patients of dialysis clinics in Brazil were treated intravenously with microcystin-contaminated water (Azevedo et al., 2002). Microcystins irreversibly inhibit eukaryotic serine/threonine protein phosphatases (e.g. 1 and 2a; MacKintosh et al., 1990; Honkanen et al., 1991) resulting in liver disease as well as nephro- and neurotoxicity (Feurstein et al., 2009). Recently, microcystins have been implicated in increased incidences of human liver cancer in China (Yu, 1995) and carcinogenic responses in rodents (Falconer and Buckley, 1989; Falconer, 1991; Nishiwaki-Matsushima et al., 1992; Ito et al., 1997). Microcystins have therefore been evaluated by the International Agency for Research on Cancer of the World Health Oganization whereby microcystin-LR was placed into category $2 \mathrm{~B}$, i.e. 'probably carcinogenic for humans' (Grosse et al., 2006).

The complex interactions among physical, chemical and biological variables that lead to the proliferation of cyanobacteria in lentic systems have been the topic of many decades of research. There is still only limited knowledge, however, of the variables that regulate toxin synthesis, e.g. microcystins, at a cellular level. Studies on Microcystis spp. (the most common microcystin producing and bloom forming species) have shown correlations between microcystin quotas (total intracellular microcystins per cell), and a multitude of physiochemical variables including: nutrients (Orr and Jones, 1998; Lee et al., 2000; Oh et al., 2000), temperature (Van der Westhuizen and Eloff, 1985) and $\mathrm{pH}$ (Van der Westhuizen and Eloff, 1983). However, results of these studies are often contradictory and environmental factors usually only induce changes in microcystin quotas three or fourfold (Sivonen and Jones, 1999).

Most studies of the regulation of microcystins have been undertaken in vitro using single strains of 
microcystin producing cyanobacteria. Such studies can allow single variables to be manipulated and effects on microcystin production to be closely monitored (e.g. Orr and Jones, 1998; Oh et al., 2000; Schatz et al., 2007). Studying cyanobacteria in these 'artificial' environments may, however, alter or remove the variables that regulate the production of microcystins. Changes in cyanobacteria maintained in culture for extended periods are also well known, for example, loss of colonial morphology in Microcystis (Zhang et al., 2007) and loss of toxin production (Schatz et al., 2005). In contrast, in-lake studies are challenging because of the plethora of interacting biotic and abiotic variables that may be critical in regulating growth of cyanobacteria and microcystin production.

Recent advances in analytical methods (e.g. ELISA and liquid chromatography-mass spectrometry) have allowed accurate monitoring of microcystins (e.g. Fischer et al., 2001; Dell'Aversano et al., 2004). Microcystins are extremely stable compounds (Tsuji et al., 1995; Harada et al., 1996) and although there is strong evidence that microcystins can be actively transported out of cells (Pearson et al., 2004), it is likely that over time there is some continuous accumulation of these compounds within cells (Young etal., 2005). Thus, measuring minor alterations in intra- or extracellular microcystins may be difficult, or impossible, when relying solely on toxin analysis.

Microcystins are synthesized non-ribosomally by a large $(55 \mathrm{~kb})$ peptide synthetase and polyketide synthase enzyme complex. The gene cluster involved in microcystin synthesis $(m c y A-I)$ has been identified and sequenced (Nishizawa et al., 2000; Tillett et al., 2000), providing the opportunity to employ molecular techniques to study microcystin production at a genetic level. Moreover, the most recently developed pseudo-viral controlled reverse-transcriptase quantitative PCR (RT-QPCR) assay (Rueckert and Cary, 2009) allows for the accurate assessment of mcyE gene expression in toxic Microcystis and Anabaena. In prokaryotic organisms mRNA is continuously degraded during translation (Voet and Voet, 2004). Using the latter RT-QPCR assay, analysis can be undertaken of temporary transcripts with an average half-life of a few minutes, thus allowing measurement of the transcriptional regulation of microcystin production almost simultaneously with the signal that induces it. The RT-QPCR assay described in Rueckert and Cary (2009) includes an internal armoured RNA standard with the same primer binding sites as the mcyE target gene, as well as a unique internal probe binding sequence. This technique provides, for the first time, a method that can be used to quantitatively measure microcystin transcriptional gene expression.

A Microcystis bloom comprising of almost entirely toxic genotypes in Lake Rotorua $\left(42^{\circ} 24^{\prime} 05\right.$ S, $173^{\circ} 34^{\prime} 57$ E,
South Island, New Zealand) provided a valuable opportunity to elucidate how interactions among abiotic and biotic variables influence microcystin synthesis in a cyanobacterial bloom. In this study an RT-QPCR assay (Rueckert and Cary, 2009) and an ADDA-ELISA (Fischer et al., 2001) were used in concert with measurement of a range of physiochemical parameters, microscopic cell counts and QPCR assays to demonstrate for the first time that microcystin synthesis is not always continuous and that changes in Microcystis cell concentrations influence microcystin production.

\section{Results and discussion}

Surface water samples were collected from a cyanobacterial bloom in Lake Rotorua (South Island, New Zealand) every $4 \mathrm{~h}$ over a $49 \mathrm{~h}$ period between 6 and 8 May 2009 , hereafter known as days 1,2 and 3. Using microscopy three cyanobacterial species were identified in surface

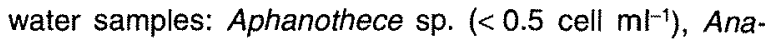
baena sp. Nova and Microcystis sp. (Fig. 1A). No Anabaena-specific mcyE genes were detected in the DNA extracted from the preserved filters using QPCR (Vaitomaa et al., 2003), indicating that all microcystins in the samples were produced by Microcystis sp. Microcystin and non-microcystin producing strains of Microcystis can coexist in lake populations (Kurmayer et al., 2002), with this difference attributed to the presence or absence of the microcystin synthetase gene cluster (Nishizawa et al., 2000). QPCR (Vaitomaa et al., 2003) was used to determine the Microcystis-specific mcyE copy numbers in all samples and the results showed high congruence with the microscopically determined cell concentrations (Fig. $\uparrow A$ ), indicating that most, if not all, cells within the population had the ability to produce microcystins.

In this study we used a recently developed RT-QPCR assay (Rueckert and Cary, 2009) to monitor mcyE gene transcripts. This assay incorporates a ribonucleaseresistant armoured RNA standard that consists of a noncontagious MS2 bacteriophage virus, in which the genome has been altered to harbour the mcyE gene, with a unique internal probe binding sequence for its differential detection. The advantage of this design is that the target and standard sequences are virtually identical, resulting in both sequences undergoing reverse transcription and amplification with the same efficiency. The armoured RNA is used to spike each individual sample, allowing monitoring for the integrity of all nucleic acid processing steps including extraction, reverse transcription, amplification and detection. Using this RT-QPCR assay, mcyE gene transcripts were detected in only four out of 14 samples (Fig. 1B). Among the positive samples there were significant up- and downregulations in mcyE gene expression over short time periods ( 2 to $5 \mathrm{~h}$ ) that 


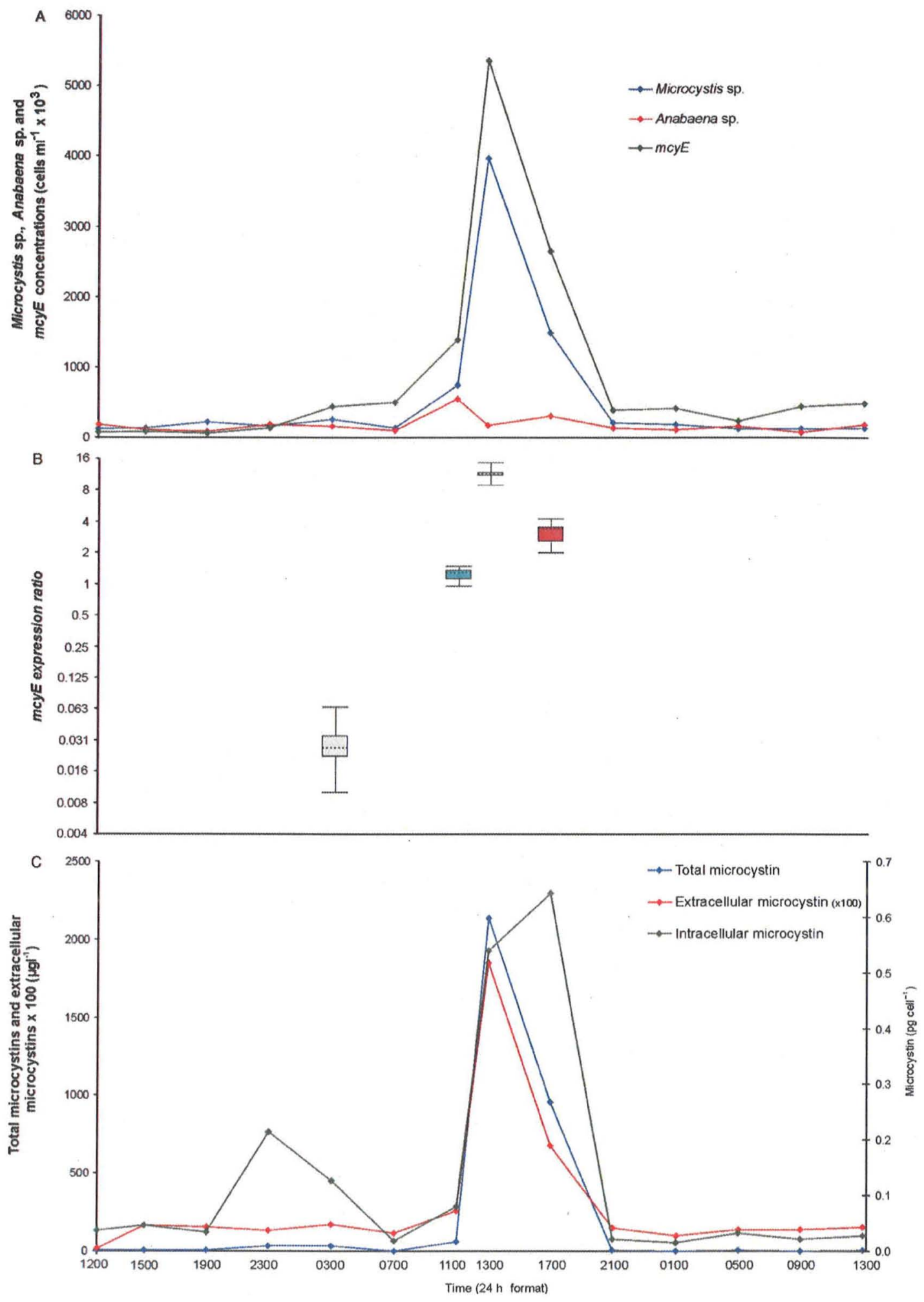


corresponded with changes in microcystin quotas. The highest mcyE expression was observed at $1300 \mathrm{~h}$ on day 2 , and this was 462 -fold greater than values from a sample collected $12 \mathrm{~h}$ earlier $(0300 \mathrm{~h})$ and 12-fold higher than a sample collected just $2 \mathrm{~h}$ earlier (Fig. 1B). By $1700 \mathrm{~h}$ expression levels had decreased but were still substantially elevated (115-fold) compared with the 0300 sample (Fig. 1B). Previous studies (Kaebernick et al., 2000; Sevilla et al., 2008) have noted variations in the magnitude of mcy gene expression; however, these studies have always been undertaken using cultured strains, and changes in mcy expression have been small and over longer time frames. Furthermore mcy gene expression has always been observed to be continuous rather than extremely variable as observed in our study. Our study is the first to demonstrate that microcystin production is not always continuous over the duration of a cyanobacterial bloom.

Microcystin quotas varied throughout the study period. Analysis using LC-MS (Wood et al., 2010) identified the microcystin variants; -YR, $-L R$, desmethyl-LR, didesmethyl-LR and WR. When microcystin concentrations were low LC-MS was not suitable for assessing minor changes in microcystin concentrations because individual variants were often below the reliable limits of detection $\left(0.2 \mu \mathrm{gl}^{-1}\right)$. The ADDA-ELISA (Fischer et al., 2001) measures total ADDA-containing compounds and in this study proved to be an accurate method for assessing small fluctuations in total microcystins (LOD, $0.02-0.07 \mathrm{ng} \mathrm{ml}^{-1}$ dependent on variants present). At 1200,1500 and $1900 \mathrm{~h}$ (day 1) the microcystin quotas ranged between $0.035-0.046 \mathrm{pg} \mathrm{cell}^{-1}$. This increased approximately fourfold in the two subsequent samples $(2300 \mathrm{~h}$ on day 1 and $0300 \mathrm{~h}$ on day 2 ; to 0.214 and $0.126 \mathrm{pg} \mathrm{cell}^{-1}$, respectively), and then decreased to $0.019 \mathrm{pg} \mathrm{cell}^{-1}$ at $0700 \mathrm{~h}$ before some recovery to $0.080 \mathrm{pg} \mathrm{cell}^{-1}$ by $1100 \mathrm{~h}$ (Fig. 1C). At 1300 and $1700 \mathrm{~h}$ (day 2) there was an approximate 15-fold increase in microcystin quotas to 0.539 and $0.644 \mathrm{pg} \mathrm{cell}^{-1}$, respectively (Fig. $1 \mathrm{C}$ ), i.e. a 28 -fold increase over a $5 \mathrm{~h}$ period $(1300-1700)$. To our knowledge no previous studies have shown such a dramatic increase in microcystin quotas of
Microcystis, and certainly not within $5 \mathrm{~h}$ (Sivonen and Jones, 1999). The observed increase in microcystin quotas could have resulted from an influx of 'more toxic' strains, as some Microcystis strains grown in culture are known to always produce greater quantities of microcystins (Bolch et al., 1997). However, the increase in microcystin quotas coupled with the upregulation of mcyE provides compelling evidence that this increase is due to some external or internal stimulus. Furthermore, given the continuously high concentrations of Microcystis cells present throughout the study ( $>115000$ cells $\mathrm{ml}^{-1}$ ) it is likely that any variations in microcystin quotas between strains would be averaged among the population.

The ecophysiological basis for microcystin production has been the topic of many decades of research, with various hypotheses postulated including: defence against grazers (Lüring, 2003), gene regulation (Dittmann et al., 2001), allelopathic interactions (Sukenik et al., 2002), intra-specific regulation (Schatz et al., 2007) and siderophoric scavenging of, and binding to metals such as iron (Martin-Luna et al., 2006; Saito et al., 2008). The data presented in this study provide some further evidence to support and refute some of these hypotheses. The most noteworthy change in a biotic variable that coincided with elevated microcystin quotas and mcyE expression was the dramatic increase in the cell concentrations of Microcystis between $0700 \mathrm{~h}$ and $1300 \mathrm{~h}$ (day 2) when there was a 30 -fold increase in Microcystis concentrations (Fig. 1A). This coincided with a period of gentle onshore winds (data not shown). Microcystis colonies are extremely buoyant, commonly forming wind-blown scums (Znachor et al., 2006), and we surmise it was the onshore wind that caused the dramatic increase in cell concentrations. The role of microcystins as a signalling or quorum sensing molecule has recently received increased attention (e.g. Dittmann et al., 2001; Schatz et al., 2007). In our study, as microcystin quotas escalated in Lake Rotorua, there was a corresponding increase in extracellular microcystin concentrations (Fig. $1 \mathrm{C}$ ), possibly indicating that the microcystins were being exported out of the cell and could be functioning as signalling compounds. However, we have no way of distinguishing between extracellular

Fig. 1. Data from surface samples collected at Lake Rotorua (South Island, New Zealand) over a $49 \mathrm{~h}$ period (6-8 May 2009 ). Water samples were preserved (Lugol's lodine) prior to identification and enumeration and frozen or filtered and frozen, for total and extracellular microcystin analysis. Samples for DNA and RNA extraction were filtered through Whatman GF/C glass microfibre filters and filters were placed immediately in LifeGuardTM Soil Preservation Solution (MO BIO Laboratories, Carlsbad, CA).

A. Microcystis sp., Anabaena sp. Nova concentrations determined using Utermöhl settling chambers (Utermöhl, 1958). Subsamples (1 mi) where settled and 10 random fields counted at $400 \times$ original magnification. McyE concentrations were assessed using QPCR (Vaitomaa et al., 2003) and data are an average of two separate analyses.

B. Relative mcyE gene expression. Statistical data analysis was performed using the Relative Expression Software Tool (REST 2005 V1.9.12 http://www.gene-quantification.info, Pfaffl et al., 2002). The boxes represent the interquartile range or the mid-point of $50 \%$ of observations. The dotted line represents the median gene expression. Whiskers represent the minimum and maximum observations.

C. Total and extracellular microcystins, and microcystin quotas as determined by ADDA-ELISA (Fischer et al., 2001). Data represent an average of two separate analyses. 
microcystins that have been exported from those that result from cell lysis. Interestingly, although mcyE expression and extracellular microcystin levels had decreased by $1700 \mathrm{~h}$ on day 2, microcystin quotas remained elevated, perhaps suggesting that cells maintain some microcystins for short periods until their requirement for microcystin abates. Microcystins are extremely stable compounds (Tsuji et al., 1995; Harada et al., 1996) and the rapid decrease in extracellular concentrations (Fig. 1C) is surprising. The most like explanation is water movement within the lake transported the microcystins out of our sampling area. Bacterial degradation may also have contributed.

The water temperatures measured in Lake Rotorua $\left(8.2-12.5^{\circ} \mathrm{C}\right.$; Fig. S1A) are well below those optimal for Microcystis growth (Imai et al., 2009). The cooler temperatures may have contributed to the rapid and pronounced changes in mCyE expression and microcystin quotas. We speculate that at these low temperatures the cells are already stressed and their response to external or internal stimuli is therefore enhanced.

No other measured abiotic variables changed markedly within the $2 \mathrm{~h}$ period (1100-1300 h), when we observed the greatest rate of change in mcyE expression and microcystin synthesis. Water temperature increased by only $1.3^{\circ} \mathrm{C}$ (Fig. S1A) and had changed little by $1700 \mathrm{~h}$ when mcyE expression had already decreased. Previous culture-based studies have shown only a onefold to twofold increase in microcystin quotas when temperatures have been increased in $>5^{\circ} \mathrm{C}$ increments (e.g. Watanabe and Oishi, 1985). Significant spikes in light intensity were recorded but these did not start until after $1300 \mathrm{~h}$ (Fig. S1A), by which time microcystin quotas and mcyE expression levels had already increased dramatically. Despite considerable evidence from culture-based studies showing the role of nutrients in regulating microcystin concentrations (e.g. Orr and Jones, 1998; Vezie et al., 2002) changes observed in dissolved nutrients in Lake Rotorua did not correlated with periods of up- or downregulation of microcystins production (Fig. S1B). Microcystis and Anabaena accounted for almost the entire phytoplankton community; therefore allelopathy does not seem like a viable explanation for the biological role of microcystins in this lake. Although Anabaena sp. Nova concentrations did fluctuate (Fig. 1A) these shifts did not align with the marked changes in microcystin synthesis.

Culture-based studies have been the mainstay of research exploring the role and regulation of microcystins. They have typically focused on environmental factors that differ throughout the duration of a cyanobacterial bloom (e.g. light, temperature and nutrients). Often only one parameter is changed while others are maintained at optimal levels. Few, if any, culture-based studies have changed conditions with the speed and intensity observed in the lake environment, for example, the 30 -fold increase in cell concentrations recorded within $6 \mathrm{~h}$ in this study. The elucidation of the microcystin biosynthetic pathway has started a new era in the search to understand the function and regulators of microcystins, and this study highlights the benefits of combining highly sensitive molecular and analytical techniques. Using a state-of-the-art technique that allowed the precise measurement of mcyE transcriptional gene expression and a sensitive method capable of measuring small changes in total microcystin concentrations, we have demonstrated for the first time that in a cyanobacterial bloom microcystin production is not always constitutive. The significant and rapid up- and downregulation of mcyE expression corresponding to variations in microcystin quota, extracellular microcystin levels and cell concentrations adds further evidence to support the hypothesis that microcystins may act as signalling compounds. Increased understanding of the regulation of microcystins in the environment will assist in assessing periods of greatest health risk and may ultimately lead to the development of models enabling real-time predictions of microcystin synthesis to be undertaken.

\section{Acknowledgements}

This research was funded by the New Zealand Foundation for Research Science and Technology (UOWX0505), a postdoctoral fellowship (CAWX0501) to SAW and a German Science Foundation grant to DRD (DI 698/18). We thank Roel van Ginkel and Michael Boundy (Cawthron Institute) for assistance with LC-MS analysis.

\section{References}

Azevedo, S.M., Carmichael, W.W., Jochimsen, E.M., Rinehart, K.L., Lau, S., Shaw, G.R., and Eaglesham, G.K. (2002) Human intoxication by microcystins during renal dialysis treatment in Caruaru-Brazil. Toxicology 181: 441446.

Bolch, C.J.S., Blackburn, S.I., Orr, P.T., Jones, G.J., and Grewe, P.M. (1997) Plasmid content and distribution in the toxic cyanobacterial genus Microcystis Kutzing ex lemmermann (Cyanobacteria: Chroococeales). Phycologia 36: 6-11.

Codd, G.A., Morrison, L.F., and Metcalf, J.S. (2005) Cyanobacterial toxins: Risk management for health protection. Toxicol Appl Pharmacol 203: 264-272.

Conley, D.J., Paerl, H.W., Howarth, R.W., Boesch, D.F., Seitzinger, S.P., Havens, K.E., et al. (2009) Controlling eutrophication: Nitrogen and phosphorus. Science 323: 1014-1015.

Dell'Aversano, C., Eaglesham, G.K., and Quilliam, M.A. (2004) Analysis of cyanobacterial toxins by hydrophilic interaction liquid chromatography-mass spectrometry. J Chromatogr A 1028: 155-164. 
Dittmann, E., Erhard, M., Kaebernick, M., Scheler, C., Neilan, B.A., Döhren, H., and Börner, T. (2001) Altered expression of two light-dependent genes in a microcystin-lacking mutant of Microcystis aeruginosa PCC 7806. Microbiology 147: 3113-3119.

Falconer, I.R. (1991) Tumor promotion and liver injury caused by oral consumption of cyanobacteria. Environ Toxicol Water Quality 6: 177-184.

Falconer, I.R., and Buckley, T.H. (1989) Tumour promotion by Microcystis sp., a blue-green alga occurring in water supplies. Med J Aust 150: 351.

Feurstein, D., Holst, K., Fischer, A., and Dietrich, D.R. (2009) Oatp-associated uptake and toxicity of microcystins in primary murine whole brain cells. Toxicol Appl Pharmacol 234: $247-255$

Fischer, W.J., Garthwaite, I., Miles, C.O., Ross, K.M., Aggen, J.B., Chamberlin, A.R., et al. (2001) Congenerindependent immunoassay for microcystins and nodularins. Environ Sci Technol 35: 4849-4856.

Grosse, Y., Baan, R., Straif, K., Secretan, B., El Ghissassi, F., and Cogliano, V. (2006) Carcinogenicity of nitrate, nitrite, and cyanobacterial peptide toxins. Lancet Oncol 7: 628629.

Harada, K.I., Tsuji, K., Watanabe, M.F., and Kondo, F. (1996) Stability of microcystins from cyanobacteria - III. Effect on $\mathrm{pH}$ and temperature. Phycologia 35: 83-88.

Honkanen, R.E., Dukelow, M., Zwiller, J., Moore, R.E., Khatra, B.S., and Boynton, A.L. (1991) Cyanobacterial nodularin is a potent inhibitor of type 1 and type $2 A$ protein phosphatases. Mol Pharm 40: 577-583.

Imai, H., Chang, K.-H., Kusaba, M., and Nakano, S. (2009) Temperature-dependent dominance of Microcystis (Cyanophyceae) species: $M$. aeruginosa and $M$. wesenbergii. $J$ Plankton Res 31: 171-178.

Ito, E., Kondo, F., Terao, K., and Harada, K. (1997) Neoplastic nodular formation in mouse liver induced by repeated intraperitoneal injections of microcystin-LR. Toxicon 35: 14531457

Kaebernick, M., Neilan, B.A., Börner, T., and Ditmann, E. (2000) Light and the transcriptional response of the microcystin biosynthesis gene cluster. Appl Environ Microbiol 66: 3387-3392.

Kurmayer, R., Dittmann, E., Fastner, J., and Chorus, I. (2002) Diversity of microcystin genes within a population of the toxic cyanobacterium Microcystis spp. in Lake Wannsee (Berlin, Germany). Microb Ecol 43: 107-118.

Lee, S.J., Jang, M.H., Kim, H.S., Yoon, B.D., and Oh, H.M. (2000) Variation of microcystin content of Microcystis aeruginosa relative to medium $\mathrm{N}: \mathrm{P}$ ratio and growth stage. J Appl Microbiol 89: 323-329.

Lüring, M. (2003) Effects of microcystins-free and microcystins containing strains of the cyanobacterium Microcystis aeruginosa on growth of the grazer Daphnia magna. Environ Toxicol 18: 202-210.

MacKintosh, C., Beattie, K.A., Klumpp, S., Cohen, P., and Codd, G.A. (1990) Cyanobacterial microcystin-LR is a potent and specific inhibitor of protein phosphatases 1 and $2 A$ from both mammals and higher plants. FEBS Lett 264: 187-192.

Martin-Luna, B., Sevilla, E., Hernandez, J.A., Bes, M.T., Fillat, M.F., and Peleato, M.L. (2006) Fur from Microcystis aerugi- nosa binds in vitro promoter regions of the microcystin biosynthesis gene cluster. Phytochemistry 67: 876-881.

Nishiwaki-Matsushima, R., Ohta, T., Nishiwaki, S., Suganuma, M., Kohyama, K., Ishikawa, T., et al. (1992) Liver tumor promotion by the cyanobacterial cyclic peptide toxin microcystin-LR. J Cancer Res Clin Oncol 118: 420-424.

Nishizawa, T., Ueda, A., Asayama, M., Fujii, K., Harada, K.I., Ochi, K., and Shirai, M. (2000) Polyketide synthase gene coupled to the peptide synthetase module involved in the biosynthesis of the cyclic heptapeptide microcystin. J Biochem 127: 779-789.

Oh, H.M., Lee, S.J., Jang, M.H., and Yoon, B.D. (2000) Microcystin production by Microcystis aeruginosa in a phosphorus-limited chemostat. App/ Environ Microbio/ 66: 176-179.

Orr, P.T., and Jones, G.J. (1998) Relationship between microcystin production and cell division rates in nitrogen-limited Microcystis aeruginosa cultures. Limnol Oceanogr 43: 1604-1614.

Paerl, H.W., and Huisman, J. (2008) Blooms like it hot. Science 320: 57-58.

Pearson, L.A., Hisbergues, M., Börner, T., Dittmann, E., and Neilan, B.A. (2004) Inactivation of an ABC transporter gene, $m c y H$, results in loss of microcystin production in the cyanobacterium Microcystis aeruginosa PCC 7806. Appl Environ Microbiol 70: 6370-6378.

Pfaffl, M.W., Horgan, G.W., and Dempfle, L. (2002) Relative expression software tool (REST ${ }^{\circ}$ ) for group-wise comparison and statistical analysis of relative expression results in real-time PCR. Nucleic Acids Res 30: e36.

Rueckert, A., and Cary, S.C. (2009) Use of an armored RNA standard to measure microcystin synthetase $E$ gene expression in toxic Microcystis sp. by reverse-transcription QPCR. Limnol Oceanogr: Methods 7: 509-520.

Saito, K., Seib, Y., Mikia, S., and Yamaguchi, K. (2008) Detection of microcystin-metal complexes by using cryospray ionization-Fourier transform ion cyclotron resonance mass spectrometry. Toxicon 51: 1496-1498.

Schatz, D., Keren, Y., Hadas, O., Carmeli, S., Sukenik, A., and Kaplan, A. (2005) Ecological implications of the emergence of non-toxic subcultures from toxic Microcystis strains. Environ Microbiol 7: 798-805.

Schatz, D., Keren, Y., Vardi, A., Sukenik, A., Carmeli, S., Börner, T., et al. (2007) Towards clarification of the biological role of microcystins, a family of cyanobacterial toxins. Environ Microbiol 9: 965-970.

Sevilla, E., Martin-Luna, B., Vela, L., Bes, M.T., Fillat, M.F., and Peleato, M.L. (2008) Iron availability affects mcyD expression and microcystin-LR synthesis in Microcystis aeruginosa PCC7806. Environ Microbiol 10: 2476-2483.

Sivonen, K., and Jones, G. (1999) Cyanobacterial toxins. In Toxic Cyanobacteria in Water: A Guide to Their Public Health Consequences, Monitoring, and Management. Chorus, I., and Bartram, J. (eds). London, UK: E\&FN Spon, pp. 41-111.

Sukenik, A., Eshkol, R., Livne, A., Hadas, O., Rom, M., Tchernov, D., et al. (2002) Inhibition of growth and photosynthesis of the dinoflagellate Peridinium gatunense by Microcystis sp. (cyanobacteria): a novel allelopathic mechanism. Limnol Oceanogr 47: 1656-1663.

Tillett, D., Dittmann, E., Erhard, M., von Döhren, H., Börner, 
T., and Neilan, B.A. (2000) Structural organization of microcystin biosynthesis in Microcystis aeruginosa PCC 7806: an integrated peptide-polyketide synthetase system. Chem Biol 7: 753-764.

Tsuji, K., Watanuki, T., Kondo, F., Ishikawa, N., Watanabe, M.F., Suzuki, S., et al. (1995) Stability of microcystins from cyanobacteria-ll. Effect of UV light on decomposition and isomerization. Toxicon 33: 1619-1631.

Utermöhl, H. (1958) Zur Vervollkommung der quantitativen Phytoplankton Methodik (Towards a perfection of quantitative phytoplankton methodology). Verh Internat Verein Theor Angew Limnol 9: 1-38.

Vaitomaa, J., Rantala, A., Halinen, K., Rouhiainen, L., Tailberg, P., Mokelke, L., and Sivonen, K. (2003) Quantitative real-time PCR for determination of microcystin synthetase E copy numbers for Microcystis and Anabaena in lakes. Appl Environ Microbiol 69: 7289-7297.

Van der Westhuizen, A.J., and Eloff, J.N. (1983) Effect of culture age and $\mathrm{pH}$ of culture medium on the growth and toxicity of the blue-green alga Microcystis aeruginosa. $Z$ Pflanzenphysiol 110: 157-163.

Van der Westhuizen, A.J., and Eloff, J.N. (1985) Effect of temperature and light on the toxicity and growth of the blue-green alga Microcystis aeruginosa (UV-066). Planta 163: 55-59.

Vezie, C., Rapala, J., Vaitoma, J., Seitsonen, J., and Sivonen, K. (2002) Effect of nitrogen and phosphorus on growth of toxic and nontoxic Microcystis strains and on intracellular microcystin concentrations. Microb Ecol 43: 443454.

Voet, D., and Voet, J.G. (2004) Prokaryotic mRNA have short lifetimes. In Biochemistry, 3rd edn, Vol. 1. Harris, D., and Fitzgerald, P. (eds). New York, NY, USA: Wiley, pp. 98-99. Watanabe, M.F., and Oishi, S. (1985) Effects of environmental factors on toxicity of a cyanobacterium (Microcystis aeruginosa) under culture conditions. Appl Environ Microbiol 49: 1342-1344.

Wood, S.A., Heath, M., McGregor, G., Holland, P.T, Munday, R., and Ryan, K. (2010) Identification of a benthic microcystin producing filamentous cyanobacterium
(Oscillatoriales) associated with a dog poisoning in New Zealand. Toxicon 55: 897-903.

Young, F.M., Thomson, C., Metcalf, J.S., Lucocq, J.M., and Codd, G.A. (2005) Immunogold localisation of microcystins in cryosectioned cells of Microcystis. J Struct Biol 151: 208-214.

Yu, S. (1995) Primary prevention of hepatocellular carcinoma. J Gastroen Hepatol 10: 674-682.

Zhang, M., Kong, F., Tan, X., Yang, Z., Cao, H., and Xing, P. (2007) Biochemical, morphological, and genetic variations in Microcystis aeruginosa due to colony disaggregation. World J Microbiol Biotechnol 23: 663-670.

Znachor, P., Jurczak, T., Komárková, J., Jezberová, J., Mankiewicz, J., Klára Kaštovská, K., and Zapomělová, E. (2006) Summer changes in cyanobacterial bloom composition and microcystin concentration in eutrophic czech reservoirs. Environ Toxicol 21: 236-243.

Zurawell, R.W., Chen, H., Burke, J.M., and Prepas, E.E. (2005) Hepatotoxic cyanobacteria: A review of the biological importance of microcystins in freshwater environments. $J$ Toxicol Environ Health B 8: 1-37.

\section{Supporting information}

Additional Supporting Information may be found in the online version of this article:

Fig. S1. Physicochemical data at sampling site at Lake Rotorua (South Island, New Zealand) over a $49 \mathrm{~h}$ period (6-8 May 2009).

A. Water temperature and light intensity (approximately $2 \mathrm{~cm}$ below water surface) recorded every 5 min (UA-002-08, HOBOQ, Onset Computer Corporation, MA).

B. Dissolved reactive phosphorous, ammonium, nitrate and nitrite concentrations determined using standard methods (APHA, AWWA, and WEF, 2005). 